\title{
An Opportunistic, and yet Appropriate, Revision of the Source Threshold for the Twenty-First Century Tax Treaties
}

\author{
Eva Escribano López*
}

The present paper aims to delve into one of the most thrilling debates set out by the Base Erosion and Profit Shifting (BEPS) Project (specifically Action 1): the reconsideration of the permanent establishment threshold.

Without disregarding the fiscal interests that have undeniably boosted the reopening of the discussion, we prefer to question the appropriateness of the PE from a different perspective. First, we will analyse the theoretical principles that originally served to justify the PE threshold. Subsequently, we will demonstrate the obsolescence of the term - as it currently stands - as a result of the challenges posed by the so-called digital economy and in light of the aforementioned principles. Some proposals for the way forward will be briefly outlined.

I The troublesome coexistence of GLOBAL BUSINESSES, DIGITAL ECONOMY, TERRITORIAL TAX SYSTEMS AND TWENTIETH CENTURY TAX TREATIES: BEPS AND ACTION I

There is little doubt that globalization and technology have disrupted the way of doing business. Some of the features that characterize new business models ${ }^{1}$ are shaking the very foundations of the current international tax law system. In this context, the Organization for Economic Cooperation and Development (hereinafter, OECD) has launched an ambitious project aimed at repairing the tax system, the so-called Base Erosion and Profit Shifting project (hereinafter, BEPS).

The underlying challenge of BEPS is to try to accommodate realities that seem hard to reconcile. On the one hand, we have global enterprises which optimize opportunities offered by cutting-edge technologies to offer better products, break into new markets and maximize their global profits while minimizing their costs (tax costs included). On the other hand, we have a heterogeneous conglomeration of domestic tax systems, designed in isolation pursuant to their sovereignty, perpetuating standards that deserve serious reconsideration and, on top of that, competing among them in order to attract foreign investments. In the middle of this chaos, bilateral tax treaties, originally conceived at the beginning of the twentieth century and largely left untouched ever since, rise as bridges between tax domestic systems, restricting taxing rights in areas where overlapping tax claims are expected.

The troublesome coexistence of these realities has resulted in two fundamental concerns ${ }^{2}$ that are contemplated in the BEPS report:

(a) Erosion of the worldwide tax base (size of the pie). Global taxpayers often exploit legal mismatches stemmed from the interaction between domestic tax systems and tax treaties which provide opportunities to eliminate or reduce significantly the global tax bill. ${ }^{3}$ This problem, undesirable per se, gains importance in the context of a revenue crisis, in which the wish to maintain the welfare system leads states to raise the tax burden upon those taxpayers whose opportunities for tax planning are more limited.

\section{Notes}

Junior Tax Lecturer and PhD Researcher at Universidad Carlos III de Madrid, Spain. Her research involves the reconsideration of current connecting factors that attach business profits to tax jurisdictions in the context of the global digital economy. This research is integrated within the R+D Project DER2013-47912-P ('Rethinking the structure and concepts of international tax law'). She can be contacted at eva.escribano@uc3m.es.

OECD, Addressing Base Erosion and Profit Shifting, 2013 (hereinafter, BEPS Report). Ch. 3 attempts to describe the main features of global business models: free movement of capital and labour, the shift of manufacturing bases from high-cost to low-cost locations, the gradual removal of trade barriers, developments in technology and telecommunications, etc.

A. Cockfield et al., Taxing Global Digital Commerce, 462 (Kluwer 2013).

BEPS Report, p. 39. The report acknowledges that mismatches may lead to the phenomenon of stateless income: 'Mismatches may in effect make income disappear for tax purposes. This leads to a reduction of the overall tax paid by all parties involved as a whole. Although it is often difficult to determine which of the countries involved has lost tax revenue, it is clear that collectively the countries concerned lose tax revenue.' Annex B of the BEPS Report (p. 61) analyses some studies regarding the effective tax rate of MNEs. 
(b) Tax jurisdiction over the worldwide tax base (share of the pie). It is also perceived that the interaction between new business models and current allocation rules in tax treaties has contributed to alter the tax balance between residence and source states. This raises the question on whether current allocation rules are still ensuring a 'fair share' among states. ${ }^{4}$

As evidenced in diverse studies both within and outside the BEPS project, the development of the digital economy has not only confirmed these concerns but further exacerbated them. ${ }^{5}$ Thus, new ways of doing business in the digital economy had, on one hand, heightened the erosion of the worldwide tax base ${ }^{6}$ and, on the other hand, threatened the tax balance between residence and source states as a result of the increasing ability of business relying on technology to perform significant and profitable economic activities within a jurisdiction without triggering a taxable presence therein in the form of a permanent establishment (hereinafter, PE). ${ }^{7}$

As to the second concern, it is hardly surprising that a change of balance of taxing powers between residence and source states would upset those seeing their share decreases. Naturally, they are the ones calling for a revision of tax allocation rules in a way that would restore the preexisting tax equilibrium. Whilst the BEPS project is not officially aimed at changing the existing international standards on the allocation of taxing rights, ${ }^{8}$ it somehow responds to the claims of these countries by means of Action 1, a line of work whose short-term scope is limited to a preliminary study of the tax challenges of the digital economy but that seems to aspire to question one of the ancient standards of the international tax system: the PE threshold, ${ }^{9}$ largely responsible for an international allocation of taxing rights in crisis.

Throughout the present paper we will first review the theoretical foundations that have traditionally supported the international share of the tax base, arguments that originally served to justify the PE threshold, a legal convention that got to become an accepted standard on the allocation of taxing rights on cross-border business profits. Then, we will critically analyse the way a physical presence threshold has been reconciled with an increasingly mobile economy. We will conclude with final considerations.

\section{INTER-NATION EQUITY AND ECONOMIC ALLEGIANCE AS PRINCIPLES UNDERLYING THE INTERNATIONAL SHARE OF THE TAX BASE}

Modern tax treaties find their origin at the beginning of the twentieth century. At that time, businesses were rapidly expanding to neighbouring countries, finding themselves in many cases liable to tax in both their state of residence and the state(s) in which they were, in one way or another, conducting business. In this context, first tax treaties came into play, responding to the double taxation issue by allocating taxing rights with respect to international income between residence and source states.

No universally agreed rules guide the division of the tax base between residence and source countries. The decision has traditionally been theoretically grounded on the ambiguous notion of inter-nation equity, ${ }^{10}$ which calls for an equitable division of the international tax revenue between the countries that are involved to some extent in the generation of international income.

Inter-nation equity considerations tend to strongly favour taxation by the source state insofar the non-resident enterprise is effectively integrated in the economic life of the host state and it can thus be assumed that it owes a certain degree of economic allegiance to the state for having enjoyed the benefits it provided $^{11}$; economic allegiance that ought to be translated into a tax liability as

\section{Notes}

BEPS Report, p. 5: 'The international common principles drawn from national experiences to share tax jurisdiction may not have kept pace with the changing business environment.' See also p. 36: 'Questions are being raised as to whether the current rules ensure a fair allocation of taxing rights on business profits.'

OECD, Addressing the Tax Challenges of the Digital Economy, 2014 (hereinafter, Action 1 Final Report). See p. 13.

J. Li, Protecting the Tax Base in the Digital Economy, United Nations Papers on Selected Topics in Protecting the Tax Base of Developing Countries, Paper No. 9 (2014). She coined the term 'base cyberisation' to refer to the erosion of the worldwide tax base as a result of the features of the digital economy. See also European Commission, Commission Expert Group on Taxation of the Digital Economy - Final Report (2014) (hereinafter, EC Final Report). Annex 2A and 2B provide an overview of the corporation tax charge in relation to income and sales for a sample of the largest digital and non-digital companies. The tables prove the fact that these companies (incidentally, all US residents, since it was easier to access to their data) pay more tax on their US earnings rather than on their non-US source earnings, the difference for digital companies being more pronounced than for non-digital ones. In 2013, for instance, while Apple's effective rate over non-US income accounts for 3.7\% and Ebay's for 5.7\%, Coca-Cola is subject to a $18.8 \%$ rate and General Electrics $26.1 \%$.

Cockfield, supra n. 2, at 462. The author understands that claims to the existing tax base may be altered as a result of the rise of e-commerce. He provides a simple example to prove his point. A company which manufactured goods and sold them abroad by a PE had to pay taxes in both the residence and source state. If the company decides to sell the goods through a website instead, only the residence state would be allowed to tax such income.

OECD, Action Plan on Base Erosion and Profit Shifting, 2013 (hereinafter, BEPS Action Plan). See p. 11.

BEPS Report, p. 35-36 and BEPS Action Plan p. 14-15.

10 P.B. Musgrave, Taxation of Foreign Investment Income - An Economic Analysis, 15-24 (Johns Hopkins Press 1963) and N. Kaufman, Fairness and the Taxation of International Income, 29-2 Law and Policy in International Business 145-203, 153 (1998).

11 Benefits that can either be general (police, fire, defence protection but primarily education, which ensures the availability and level of labour) or specific (policies that benefit the conducting of business such as keeping Exchange rates stable and interest rates low). See D. Pinto, E-Commerce and Source-Based Income Taxation, 19 (IBFD 2003). 
a sort of compensation for the costs incurred by the host state that contributed to the earning of the income. ${ }^{12}$

Hence, the fundamental question that needs to be addressed when dividing the tax base over international income in a tax treaty is under which circumstances and to what extent the source country should be permitted to tax the income that the non-resident entity derives from its investment therein. According to the aforementioned principles, the answer should take into consideration the level of involvement of the non-resident entity in the economic life of the host state, which serves as an indicator to measure the degree of enjoyment of benefits provided by the aforementioned state.

\section{The Pe as an opportunistic legal CONVENTION IN ACCORDANCE WITH THE BUSINESS CONTEXT OF THE TIME}

First tax treaties had to respond to the question of whether and under which circumstances source-based taxation ought to be allowed. This implied drafting a rule that was clear, easy to apply, administrable and that furthermore revealed, in line with the principles outlined above, a sufficient grade of participation within the economic life of the source state to the extent a hypothetical benefit from the services provided by the state could be assumed.

Such a rule could not however be grounded on a prior notion of source of income, since source is a not selfdefining concept ${ }^{13}$ that we could be infer from the nature of things. Economists have attempted to shed some light when determining the profits' source from a theoretical point of view. They consider two approaches: ${ }^{14}$ (a) supply approach, which identifies the source to the place where the factors generating the income operate and (b) supply- demand approach that states that profits are created through the interaction of supply (factors of production) and demand (where the market is located). The supply approach has historically been preferred, ${ }^{15}$ arguing that we cannot assume a sufficient degree of involvement of the non-resident taxpayer in the economic life of a state that merely provides the market for goods and services. Despite the useful insight provided by economic literature, a threshold was needed to be configured for practical purposes, and considering the non self-defining nature of source, such a threshold could not aspire to become more than a legal convention.

The PE concept ${ }^{16}$ succeeded to become such legal convention, thus being incorporated to first income tax treaties and subsequent model tax treaties. ${ }^{17}$ Since its early manifestations, the PE has always relied on a high degree of physical presence in the host state, a presence that has traditionally taken two forms: a) A fixed place of business through which the business of the enterprise is wholly or partly carried on (preparatory and auxiliary activities aside) and b) A dependent agent acting on behalf of the enterprise and habitually exercising an authority to conclude contracts in the name of the enterprise.

The original idea behind the PE threshold was that the degree of economic presence revealed by the fulfilment of its requirements was considered as a proper evidence of the economic allegiance to the state in which the PE was located. ${ }^{18}$ After all, the economic context in which the PE concept arose is a context characterised by the so-called brick-and-mortar business models. ${ }^{19}$ Thus, in a context in which a physical presence was critical to perform any kind of business activities (including the provision of almost all services), a threshold entirely based on this parameter seemed to be an appropriate way to measure a sufficient degree of involvement in the economic life of the host

\section{Notes}

The notion of economic allegiance as a basis to share the tax base among jurisdictions was first introduced by G. Schanz, Zur Frage der Steuerpflicht, 9 FinanzArchiv 1-174 (1892). See K. Vogel, Worldwide vs. Source Taxation of Income: A Review and Re-evaluation of Arguments (Part III), 11 Intertax 393-402, 398 (1988): 'The only valid legitimation therefore can be derived from benefit aspects. Usually it is the state of source that has provided most or all of the benefits relevant for the production of the income.' Also in this line, R. Avi-Yonah, International Taxation of Electronic Commerce, 52-3 Tax Law Review 507-555, 520 (1997): 'These benefits justify source-based corporation taxation in the sense that the host country's government bears some of the costs of providing the benefits that are necessary for earning the income'.

K. Vogel, Worldwide vs. Source Taxation of Income: A Review and Re-evaluation of Arguments (Part I), 8-9 Intertax 216-229, 223 (1988).

P.B. Musgrave, The State Corporation Income Tax - Issues in Worldwide Unitary Combination 234 (C. McLure ed., Hoover Institution Press 1984).

OECD, Are the Current Treaty Rules for Taxing Business Profits Appropriate for E-Commerce? - Final Report, 2003 (hereinafter, 2003 Report). See p. 14.

16 A. Skaar, Permanent Establishment: Erosion of a Tax Treaty Principle, 72 (Boston Kluwer Law and Taxation Publishers 1991). The Bestriebsstätte ('fixed physical location'), considered to be the immediate antecedent of the PE, was first used in Prussian municipal tax regulations which allowed a municipality to tax income earned by an individual living in another municipality as long as the individual had a 'fixed physical location' in the former one.

17 The PE threshold was included in the first commonly regarded international tax treaty signed by Austria-Hungary and Prussia in 1899 . Here the term was no longer used as part of a definition (as happened in the Prussian municipalities regulations) but rather became the concept that had to be defined as the sole proxy to establish the source of business income. Later on, the League of Nations borrowed the concept and integrated it into its first Model Convention in 1928, a Model that heavily relied on the 'Report on Double Taxation' submitted to the League of Nations by Professors Bruins, Einaudi, Seligman and Sir Josiah Stamp in 1923.

18 Skaar, supra n. 16, at 559: 'The conventional wisdom is that an enterprise with a foreign PE has extended its activities abroad to such a degree that the benefits from this country's expenditure networks justify taxation in that country.'

19 D. Tillinghast, The Impact of the Internet on the Taxation of International Transactions, 50-11 Bulletin for international fiscal documentation 524-526, 524 (1996): 'The existing body of international tax rules, as reflected both in national law and in treaties, is based in large part on the supposition that international trade consists of the physical shipment of tangible goods or the physical movement of persons to perform services at different locations.' 
state, sufficient enough to trigger taxing rights by the latter state. ${ }^{20}$

Notwithstanding the fact that a threshold based on physical presence seemed undoubtedly in accordance with the economic context of the time, the truth is that it was not equally welcome by everybody. Clearly the way source was conceptualized was not accidental but rather an opportunistic option for capital exporting countries. Both the League of Nations and the OECD later on consolidated their preference for residence-based taxation by adopting a high threshold to minimize source-based taxation, thus satisfying the fiscal interests of the capital exporting countries of that time. ${ }^{21}$

Consequently, both the initial success and the survival of the PE over the decades have been intimately bound to the continued presence of these two factors, the brick and mortar economy on one hand, and the fiscal interests of the capital exporting countries, represented by the OECD, on the other. This way, it has become a core element in the international tax systems, present in virtually all modern tax treaties, ${ }^{22}$ with a wording that has remained almost unchanged since its origin.

First pressures upon the concept came long before the so-called digital economy, even long before the spreading of the internet in the mid-1990s with the arrival of the World Wide Web. Progress in communications and a then incipient use of technologies were making large establishments and substantial machinery or equipment progressively less essential to carry out extensive and profitable business activities. As a consequence of the changing business environment, Arvid Skaar anticipated back in 1991, that the effects of the PE concept in international fiscal law had dramatically changed: 'Rather than protecting the tax base in the source state, the PE principle today has become instrumental in ensuring avoidance of sourcestate taxation for some economically important business operations'. ${ }^{23}$ This assertion reveals a problem we are now facing as new in the BEPS context.

As communications and technologies were rapidly changing the way business were conducted, allowing a substantial interaction with the host state without triggering a taxable presence therein by means of the PE threshold, doubts on the provision were progressively growing. Was the threshold PE an appropriate parameter to measure the level of involvement of the non-resident within the host state? Did it constitute a reliable and suitable indicator of the hypothetical degree of enjoyment of benefits provided by the aforementioned state?

The OECD has dealt with the challenges that the new economy have posed on the PE provision in two ways. First, insisting on the convenience of the provision and adapting its interpretation to the new realities. And secondly, calling into question its suitability and considering other alternatives.

\section{I Adherence to the PE Standard and Its Reinterpretation as a Way to Address First Pressures on the Term}

A phenomenon that demanded the immediate attention of the OECD was the automation of functions, which slowly started to allow a certain economic interaction with the market by means of a presence that arguably fell under the scope of the traditional PE concept. At that point the question of whether a PE could be triggered without human intervention was raised. The OECD responded positively in relation to automatic equipments (gaming and vending machines), stating that a PE in the form of an automated machine could be deemed to exist just as long as the non-resident enterprise (or its dependent agent) was in charge of setting up, operating, controlling and maintaining the equipment for its own account. ${ }^{24}$

However, it was the advent of the information and communications technology and the popularization of the internet for both consumers and businesses what further exacerbated the pressures upon the concept. The raising phenomenon of e-commerce ${ }^{25}$ seriously shook the foundations upon which the PE was originally built by facilitating the remote trading of goods and provision of

\section{Notes}

20 This assumption remains on the current Commentary on the provision of Art. 7(1) of the OECD Model Convention, para. 9: 'It is perhaps sufficient to say that it has come to be accepted in international fiscal matters that until an enterprise of one State sets up a permanent establishment in another State it should not properly be regarded as participating in the economic life of that other State to such an extent that it comes within the jurisdiction of that other State's taxing rights'.

21 M. Graetz \& M. O'Hear, The 'Original Intent' of US International Taxation, 46 Duke L. J. 1021-1110, 1074-1089 (1997). This paper discloses the active support of the US for the PE threshold in the debates within the League of Nations back in 1920s, due to their concern with protecting the interests of US businesses operating overseas. On the other hand, see S. Zapata, The Latin America Approach to the Concept of Permanent Establishment in Tax Treaties with Developed Countries, $52-6$ Bulletin for International Fiscal Documentation 252-261, 252-253 (1998). Zapata addresses the long fight leaded by developing countries against the PE concept, which eventually resulted in the 1943 Mexico Draft of Model Convention and the Andean Pact Model where the PE is just an example of source taxation of business profits.

22 Articles 5 and 7(1) of the OECD, UN and US Model Conventions. Definitions of PE in the OECD, UN and US Model Conventions agree on the basics. The UN PE is nevertheless significantly wider to the extent that it requires a six-month period for constructions PE (instead of twelve) and furthermore includes a service PE clause.

Skaar, supra n. 16, at 559

24 Commentary number 10 to Art. 5(1) OECD, renumbered and amended on 23 Jul. 1992, pursuant to the interpretation already followed by previous judgments and academic papers, some of them commented in Skaar, supra n. 16, at 194

25 In 2009 OECD member countries endorsed the following definition of e-commerce: 'An electronic transaction is the sale or purchase of goods or services, conducted over computer networks by methods specifically designed for the purpose of receiving or placing of orders'. Two varieties of e-commerce are distinguished: (a) Offline or indirect e-commerce which consists on the ordering of goods or services that are then delivered through conventional channels, and (b) Online or direct e-commerce when both the ordering and delivering of the goods or services are performed electronically. See OECD, Guide to Measuring the Information Society, 2011 , p. 72 for further details. 
services and thus allowing businesses to conduct significant business in a market without the need of having a physical fixed presence therein. Several international organizations and states laid their eyes on this new reality and studied whether a reconsideration of tax rules was justified at that point.

E-commerce brought new interpretative issues in relation to $\mathrm{PE}$, issues that needed to be addressed without delay by the OECD to ensure a uniform and coordinated understanding of the term that could prevent conflicts of interpretation and the subsequent unintended double taxation. As expected, new realities originated in the ecommerce context would hardly fit in a nineteenth century category. Websites, described as a mere 'combination of software and electronic data' did not fulfil the first requirement of the PE threshold insofar as an intangible property could never constitute a place of business. ${ }^{26}$ With regard to servers, ${ }^{27}$ it was agreed that they could constitute PEs only when certain requirements were met: (a) the server should be effectively at the disposal of the non-resident enterprise and (b) activities carried out through it could not be of preparatory or auxiliary activities. ${ }^{28}$ Undoubtedly such interpretation is in accordance with the wording of Article 5 of the OECDMC and seems only reasonable from a formal point of view. The conclusion to which this interpretation brings us is, however, absurd and contrary to the alleged purpose of the term, which is to provide a legal minimum threshold that denotes a significant economic involvement with the host state that allows us to assume a hypothetical benefit from the services provided by such state. The sole presence of a server does not manifest per se any kind of participation in the economic life of the host state beyond the presence of a dusty computer running in the basement of a building. ${ }^{29}$ On top of that, the taxpayer can easily circumvent the constitution of the PE as long as the server is not at his/her disposal, something easy to achieve thanks to the widespread 'hosting arrangements' through which the non-resident taxpayer does not rent the server as such but an amount of disk space to store his or her website. ${ }^{30}$

Adherence to the current literal wording of the PE and its reinterpretation as a way to address the challenges of the new economy has proved insufficient, to the extent that it has led to unsatisfactory and inconsistent results, as so well illustrated by the invention of the server PE in the questionable 2000 Update to the Commentaries of the OECD Model Convention.

Over time, the weakening of the relation between physical and economic presence is becoming increasingly evident. A physical presence within the meaning of the PE clause cannot be understood anymore as the sole, true and infallible indicator of a substantial economic presence in the host state that permits us to assume the enjoyment of benefits that justifies source-based taxation. ${ }^{31}$ Thus, in the same way that a PE may not express any kind of significant economic involvement within the host state (as illustrated by the server case), it is equally possible to witness a significant economic presence that does not express itself in the terms required by the PE clause.

Consequently, it feels necessary to rewrite the source threshold, looking for new indicators that effectively reflect a significant level of involvement in the host state and with such a degree of economic allegiance that it becomes justifiable for the state to access part of the tax base. This exercise must necessarily be accompanied by the understanding of the new economic reality and the challenges posed by the use of technology in business models.

\subsection{Rethinking the Source Threshold in Tax Treaties. The Beginning of the End of the PE?}

Being fully aware of the inherent limits of the PE threshold in the light of the new economic reality, the

\section{Notes}

26 Commentary 42.2 to Art. 5 OECD Model Convention, under the Electronic Commerce section, (42.1 to 42.10) which was entirely adopted by the CFA in December 2000. Greece, Spain and Portugal expressly reserved their rights to not to follow this position. Spain withdrew this observation in the 2010 update of OECD MC, fact that did not prevent the Spanish Central Economic-Administrative Court (TEAC) from deeming the Dell website operated by Dell France as a PE in Spain and therefore attributing all profits earned from online sales to it. See J.M. Calderón \& E. Martínez-Matosas, Spanish Court Rules on Permanent Establishments in Dell, 68-4 Tax Notes International 385-387 (2012)

Servers are equipments on which websites are stored.

28 Commentaries 42.2 to 42.9 on Art. 5 OECD Model Convention. To date only UK has reserved the right not to follow this interpretation (Commentary 45.5). For a comprehensive analysis of cases arisen worldwide regarding the server PE see Cockfield, supra n. 2, at 127-133.

29 R. Doernberg \& L. Hinnekens, Electronic Commerce and International Taxation, 7 (Kluwer Law International 1999): 'Servers can easily be located anywhere and their location is generally unknown and unimportant in a business transaction.' In fact, Google registered a patent back in 2008 which consisted on the installation of mobile data centre platforms at the sea by stacking containers filled with servers and storage systems. See http://bits.blogs.nytimes.com/2008/09/07/googles-search-goes-out-to-sea/? _php $=$ true\&_type $=$ blogs\&_r $=0$

30 For further arguments suggesting the OECD approach is flawed see A. Cockfield, The Rise of the OECD as Informal World Tax Organization through National Responses to E-Commerce Tax Challenges, 8 Yale J. L. Tech. 136-187, 172 (2006).

31 Skaar, supra n. 16, at 559-560: 'A PE is merely a piece of evidence of economic allegiance, not the reason for source-state taxation.' With such assertion, Skaar wishes to explain that the PE does not cover all cases in which source-based taxation could be justified. He proves his point by referring to the case of a short-term business operation accumulating substantial profits from domestic profits and benefiting substantially from the infrastructure of the host state even in the absence of a PE. In this line, the 1943 League of Nations Mexico Model Treaty and the Andean Pact retain the PE threshold as only an example to justify the source-based taxation of business profits, coexisting with other indicators. 
Committee on Fiscal Affairs, in parallel to the discussion on the aforementioned 2000 Update of the Commentaries, set up a Technical Advisory Group with the mandate to examine proposals for alternative rules for taxation of business profits in the context of electronic commerce. The TAG work lead to the publication of a final report in 2003, which assessed the appropriateness and feasibility of a number of alternatives to current treaty rules, all of them implying a more or less fundamental change on the wording of Articles 5 and/or 7 of the OECD Model Convention. ${ }^{32}$ The first set of alternatives involved minor modifications of existing rules, some of them reducing the scope of the $\mathrm{PE}^{33}$ some others enlarging it. ${ }^{34}$ It was concluded that all these options should not be pursued at that time, without prejudice to a further study on two of them, namely: a reconsideration of the list of exceptions in Article 5(4) and the inclusion of a service PE. On the other hand, the second set of alternatives involved more significant changes to existing rules, ${ }^{35}$ where we note with surprise the consideration of formulary apportionment for groups of companies. These options were discarded straightaway, the reason being that there was no evidence that the communications efficiencies of the internet had caused a 'significant decrease to the tax revenues of capital importing countries'. ${ }^{36}$

Now BEPS takes up the baton left by the aforementioned report and reopens the debate that was put on hold in 2003. The reason why BEPS retrieves the dialogue on the suitability of the PE clause lies fundamentally on the pressure exerted by those states that have suddenly become 'losers' in the new residence-source balance. Major markets of the US-based digital companies, particularly European ones, are those claiming with greater impetus a share on the tax base of these companies. ${ }^{37}$ Developing countries, on the other hand, despite providing a significant market to those companies, are not raising their voices at the same level. ${ }^{38}$

The market, a historically despised factor, 39 seems to come back to life. The first thing that strikes us is precisely the constant references to the market jurisdiction in both the draft and the final report, ${ }^{40}$ a fact that seems to reflect the desire of many OECD member countries to bring the source threshold closer to where the consumers are. When highlighting common features in the tax planning schemes of MNE, the report observes that they succeed to avoid a taxable presence in market jurisdictions in part due to the 'artificial' avoidance of the PE status under the scope of action $7^{41}$ - but fundamentally due to the current wording of allocation rules. ${ }^{42}$

The final report superficially describes a number of potential options. ${ }^{43}$ They all have in common that their eventual adoption as source threshold in tax treaties would allow the market states to tax business profits of the nonresident company arisen therein, thereby fulfilling the claims originated in Europe. It should be noted that the idea of reformulating the source threshold in this direction, although novel in the OECD work, has been discussed and supported by many scholars ${ }^{44}$ who find the

\section{Notes}

2003 Report.

$33 \mathrm{Ibid}$. at 30-38. (a) Exclusion of activities that do not involve human intervention, (b) exclusion of the possibility of a server becoming a PE and (c) exclusion of functions attributable to software when applying 5(4).

34 Ibid. at 38-51. (a) Elimination or simplification of 5(4), (b) elimination of the 5(4) exceptions related to storage, display or delivery, (c) force of attraction rule dealing with e-commerce and (d) Service PE.

35 Ibid. at p. 51-72. (a) Withholding tax on payments related to some forms of e-commerce, (b) withholding tax on base eroding payments arising in a country, (c) virtual PE (allowing the consideration of a website as a PE) and (d) the abandonment of the separate entity approach and the arm's length principle in favour of a formula solution.

36 Ibid. at 72 .

37 Particularly France, who has taken the lead towards a change of paradigm.See the Colin \& Collin report on Taxation of the Digital Economy submitted by two French officials to the French Ministry of Finance (January 2013) http://www.hldataprotection.com/files/2013/06/Taxation_Digital_Economy.pdf.

$38 \mathrm{Li}$, supra $\mathrm{n}$. 6, at 3. Li points out that developing countries are generally market countries and net digital importers and, being market countries, they tend to be net losers in tax revenue as well (p. 27). However, she observes that the voice of developing countries is largely absent in the debate, something that was revealed by the absence of public comments sent on the Discussion Draft on Action 1 published in April 2014. Among the reasons that may help to explain this are a lower level of connectivity than the OECD average (p. 8) and the lack of adequate infrastructure to enable businesses to achieve the full potential of e-commerce (p.12).

392003 Report, p. 14.

40 There are 46 references along the 202-pages Action 1 Final Report. See Y. Brauner, What the BEPS?, Working Paper (2014): http://ssrn.com/abstract=2408034 p. 18: 'The language may imply that the OECD wishes to reform and regulate the entire taxing regime applicable to cross border digital business income'.

41 Action 1 Final Report, p. 102. Action 7 will cover problems arising from the artificial avoidance of the PE status by either the use of commissionaire arrangements or fragmenting operations among multiple group entities in order to qualify for the exceptions to PE status for preparatory and auxiliary activities.

42 We share Martín Jiménez's view that the policy solution is preferred to the anti-avoidance one: 'If drafted clearly and having administrability in mind, they are often much easier to apply that anti-avoidance rules or doctrines or transfer pricing legislation'. See A. Martín Jiménez, Preventing the Artificial Avoidance of PE Status, United Nations Papers on Selected Topics in Protecting the Tax Base of Developing Countries, 55 (2014).

43 Options a and d are recovered from the 2003 Report, option b was included in the Discussion Draft on Action 1 published in March 2014 and finally options c and e have been more recently incorporated as suggested in the Public Comments received by the stakeholders as response to the Discussion Draft.

44 Idea that finds support in many academic papers, see for example Skaar, supra n. 16, at 23: 'It may for example be justifiable to include in the concept of income source not only the country where the product is physically produced but also the country where the commercial need for the product is originated'. See also Vogel, supra n. 12 , at 
claims of the market states legitimate to the extent that a certain enjoyment of benefits by the non-resident in that states may be assumed: 45

a) Modifications to the exemptions from PE status. ${ }^{46}$ It is under discussion whether some of the activities that now qualify as auxiliary or preparatory may have become core functions in new business models. For example, if the need for quick delivery to clients is considered to be a key element in the business model of e-sellers of tangible products, it thus becomes doubtful whether the maintenance of a local warehouse should still qualify as an auxiliary activity.

b) Significant digital presence. Nexus complementary to the existing PE that would target enterprises whose business activities are conducted wholly digitally. A number of indicators to identify such enterprises are suggested, for example, when the business relies mostly on digital goods and services, or when the communication with the customers is generally conducted remotely via the internet or by telephone. Such digital presence would only trigger source-based taxation as long as it exceeds certain thresholds, for instance, a significant number of contracts for the provision of digital goods or services. It is also noted that the nexus may cover the regular and systematic monitoring of Internet users of the country to collect their personal data. ${ }^{47}$

c) Significant presence. This nexus would replace the existing PE in order to cover both physical and non physical presence in the source state to the extent it exceeds a certain threshold. The criteria that is suggested as threshold would be: (a) relationship with customers extending over six months and combined with some physical presence in the country, (b) sale of goods or services by website as long as there is a certain use of local infrastructures (delivery, banking and other facilities, etc.) and finally (c) provision of goods or services to customers in the country resulting from or involving systematic data-gathering. ${ }^{48}$

d) Withholding tax on digital transactions. The rule would allow the imposition of a withholding tax on certain payments made by residents of a country for digital goods or services provided by foreign providers. The implementation would most likely require the collaboration of financial institutions as withholding agents. ${ }^{49}$

e) Bit tax. Finally, this option consists on taxing the websites' bandwidth use. The taxable base would depart from the number of bytes used by the website but would also introduce an element of progressivity such as the turnover of the enterprise. ${ }^{50}$

The conclusion of the final report seems however a bit watered-down. It is concluded that the implementation of these potential options would be premature at this stage, and hence it is convenient to wait for the outcome of the rest the actions which is likely to alleviate some of the problems diagnosed by Action 1. For instance, measures addressing the circumvention of the PE status through commissionaire arrangements would allow the market state to tax profits arisen therein by the nonresident enterprise. Nevertheless, the report promises to continue the assessment of such alternatives in parallel to the work on the 2015 deliverables. Conclusions on that assessment would be brought back to the table in case the outcome of the remaining actions is not deemed satisfactory.

\section{Notes}

400-401: 'States have claimed to tax income received from sales to their residents reasoning that this income would not have been earned without the market they provide' and R. Avi-Yonah, Globalization, Tax Competition, and the Fiscal Crisis of the Welfare State, 113-7 Harvard L. Rev. 1573-1673, 1670-1675 (2000).

45 Pinto, supra n. 11, at 21-23. Pinto argues that companies that do not maintain a physical presence in the market jurisdiction still may benefit from this state's benefits insomuch as they rely upon its legal system (to enforce payment for transactions, uphold intellectual property rights or maintain a pro-competitive business environment), benefit from its infrastructures (a suitable telecommunications infrastructure that favours the access to the internet by citizens or roads upon which delivery vehicles can travel) and use its public services (waste disposal for packaging materials).

46 Action 1 Final Report, p. 143. The proposed options are: (a) Eliminate 5(4) entirely, (b) Eliminate subparagraphs a through d, (c) make the availability of the exceptions subject to the condition that the character of the activity conducted be preparatory or auxiliary in nature in the Enterprise in question or finally (e) eliminate the world delivery in 5(4) (a) and (b) in order to exclude from these subparagraphs certain types of warehouses

47 The Collin \& Colin Report, supra n. 37. The report emphasizes the importance of data as a key resource in the digital economy for various reasons. One of them is its use for target advertising that is adapted to the user's profile and interests, potentially increasing the consideration an advertiser may be willing to pay for such personalized advertisements. The report maintains that the unprecedented value of data converts Internet users in a huge 'free labour' market to the extent that they provide valuable data that is directly related to the profitability of the digital business while not receiving any monetary consideration in exchange. In p. 114, the report concludes that the notion of PE should capture the free labour phenomenon, meaning the 'economic activities generated in a given country by the voluntary collaboration of application users in the production process of a foreign company'.

48 The significant economic presence threshold has been widely discussed by scholars, who have suggested two types of tests. The first one is the 'qualitative economic presence test', defended mainly by Hinnekens. He does not provide a specific wording but rather a facts-and-circumstances test requiring a continuous, systematic and focused business in the host state: 'More than a simple counting exercise, the finding of nexus would be made part and parcel of bundled facts-and-circumstances determination'. The second alternative is a 'quantitative economic presence test', the option preferred by Avi-Yonah. He suggests the addition of 5(3) to Art. 5 on PE, allowing source-based taxation when a 'remote seller has gross annual receipts in total remote sales in a contracting State in the preceding calendar year exceeding 1 million USD, whether such remote seller satisfy any other definition in this Article 5 or not'. See L. Hinnekens, Looking for an Appropriate Jurisdictional Framework for Source-State Taxation of International Electronic Commerce in the Twenty-first Century, 26-6 Intertax 192-200, 195-199 (1998) and R. Avi-Yonah, A Model Treaty for the Age of BEPS, Law and Economics Research Papers, Paper 411, University of Michigan (2014).

49 Pinto, supra n. 11, at 207-231. The author describes and evaluates the possibility of implementing this alternative.

so Hinnekens, supra n. 48, at 193. Hinnekens criticized this alternative when first proposed in the 1990s. First because it unduly burdens the new medium and second because bits and bytes are not an expression of economic value or wealth. 
Many factors may be able to explain the temporary abandonment of this line of work, being the most predictable one the likely strong resistance of the US in any dialogue intended to broaden source-based taxation. ${ }^{51}$ Particularly when the majority of the raised proposals options b, d, e- seem to target digital companies, mostly tax residents in the US. ${ }^{52}$

Foreseeing the obstacles that a reformulation of source would face within the OECD, it is interesting to consult the work carried out in other international foras where the hypothetical impediments of the US would be absent. In this line, it is worth noting the report presented by a group of experts to the European Commission, which advocates for a substantial reform in the long-term. ${ }^{53}$ On the one hand, it reopens the debate of the failed CCCTB proposal, ${ }^{54}$ on the other, it refers to the preliminary studies on the so-called destination-based corporate tax. ${ }^{55}$ This proposal takes the customers' location as the main legal proxy, considering that the market jurisdiction has both legitimacy to tax and effective means to collect. Its functioning would be similar to VAT in the sense that exports would be zero-rated and imports would be taxed, but different to the extent that wage costs would continue to be deductible and tax would be levied on an accounting basis rather than using the invoice-credit method.

\section{Final considerations}

When reality reveals the expiry of an old system of rules, there are basically two options to be followed. On the one hand, cling to the system and insistently add patches to it in a desperate attempt to keep it alive and, on the other hand, start with a clean sheet, question everything we have so far taken for granted and try to figure out solutions that better adapt to reality. This is basically the dichotomy that states are now facing when addressing the monumental challenge of accommodating global business, territorial tax systems and twentieth century tax treaties.

It appears that BEPS has opted for the first option. The brave, out-of-the-box reform promised by the BEPS report, has been watered down by an Action Plan which, at one stroke, left out of the debate two of the main pillars that sustain the tax system (separate entity approach and standards on the allocation of taxing rights). And what is worse, the most disruptive of the actions, number 1 , seems doomed to failure given the predictable internal resistances within the OECD forum. Hence, the outcome we could expect from BEPS will not be the promised comprehensive reform but rather a combination of measures aimed at restoring the effectiveness of current principles.

Hence, the study and discussion on a comprehensive reform aimed at a true alignment between economic activity and tax jurisdiction ${ }^{56}$ will, in all likelihood, remain in the academia. This exercise may start from the same theoretical foundations that once helped to justify the current standards. That is, on the one hand, the internation equity principles, which calls for an equitable division of the worldwide tax base among the states involved to some extent in the generation of the crossborder income. On the other hand, the economic allegiance principle, which advocates for attributing taxing rights to the states that have contributed with their infrastructures and services to the generation of the income by the taxpayer. That said, it would be essential to look for new indicators of economic allegiance considering the new economic context. The result of the proposed exercise would likely result in a model based on formulas, ${ }^{57}$ leaving behind the crumbling residence-source paradigm as well as the separate entity approach.

\section{Notes}

51 D. Spencer, The OECD BEPS Project: Tax Challenges of the Digital Economy (Part 1), 25-1 J. Intl. Taxn 30-41 (2014). Spencer quotes Danielle Rolfes, US Treasury International Tax Counsel: 'Treasury will not countenance fundamental changes to the permanent establishment rules, which some other countries clearly want (...) Some tweaking of the PE rules may be warranted (...) Any tweaking should not take the form of a digital commerce'.

52 J. Carr et al., BEPS Action Plan: a Case Study of the Potential Implications for a U.S. Based Multinational, 73-11 Tax Notes International 1031-1037, 1035-1036 (2014). The paper anticipates some of the measures that may come out of the BEPS Project and apply them to an ordinary tax planning scheme followed by US MNEs. It briefly comments the implications of reformulating source but deems a departure from PE as highly unlikely considering the statements by the US Treasury.

53 EC Report, p. 47-50. It is noteworthy the fact that Pierre Collin, co-author of the influential Collin \& Colin Report, was appointed as member of this expert group.

54 While once considered in the EU, formulary taxation has traditionally been discarded in the OECD forum for being politically unrealistic and technically unworkable as long as there is no international uniformity in the basic elements of Corporate Income Taxation (e.g., an internationally accepted measure of income). See OECD, E-commerce: Transfer Pricing and Business Profits Taxation, 143-144 (2005).

55 This proposal was first presented by Avi-Yonah, supra n. 44. More recently, as part of an ongoing study, it has been published the following working paper which is more focused on implementation issues: R. De la Feria \& M. Deveraux, Designing and Implementing a Destination-based Corporate Tax, Oxford University Centre for Business Taxation Working Paper Series, WP 14/07 (2014).

56 We should remember that this is the alleged main ambition of the BEPS project. See BEPS Report, p. 8 and 51

57 See K. Clausing \& R. Avi-Yonah, Reforming Corporate Taxation in a Global Economy - A Proposal to Adopt Formulary Apportionment (The Brookings Institution 2007) and W. Hellerstein, The Case for Formulary Apportionment Income Allocation in the 21st Century : the End of Transfer Pricing?, 12-3 Intl. Transfer Pricing J. 103-111 (2005). 